\title{
POWER AND CONTROL AS MEANS TO EXPLORE TEACHERS' PRACTICE IN THE ONE-TO-ONE COMPUTING CLASSROOM: IS THERE A SHIFT FROM TEACHER-CENTERED PRACTICE TO STUDENT-CENTERED PRACTICE?
}

\author{
Peter Bergström \\ Umeå University, Department of Applied Educational Science \\ Johan bures väg 13, SE-901 87 Umeå, Sweden
}

\begin{abstract}
This paper reports on a study about teachers' practice in one-to-one computing classrooms in Social Studies in upper secondary school. In the study, two teachers were followed in their daily practice with students where the observer collected empirical material through classroom observations, informal discussions and interviews. The teachers taught both academic and vocational programs in Social Studies and all students were equipped with a personal laptop. The aim and research questions demonstrate an attempt to both explore and explain how different power and control relations contribute to describe these teachers' practice as either teacher-centered or student-centered. The theoretical framework was based on Bernsteins' theory regarding symbolic power and control. Both teachers used one-to-one computing to extend the students learning outside the school building but they demonstrated two different theoretically informed practices. These teachers' practice involved the students to different extent in the decisions about, for example, content, sequence and how the classes should be organized individually or in groups. The different teaching approaches reflects how the teachers either kept or distributed power and control to the students. The findings contribute to understand the differences between teacher-centered and student-centered practice.
\end{abstract}

\section{KEYWORDS}

One-to-one Computing, Power and Control, Teachers' Practice, Teacher, Student

\section{INTRODUCTION}

This study is part of a larger Nordic research project, including a series of substudies with a common research objective of examining teachers' practice in one-to-one computing classrooms in Denmark, Sweden and Finland (Jahnke, Bergström, Mårell-Olsson, Häll \& Kumar, 2017, Bergström, Mårell-Olsson \& Jahnke, 2017; Bergström \& Mårell-Olsson, 2018). One-to-one computing includes one personal laptop or tablet for each student, wireless internet (WiFi) in school buildings, and a setup of appropriate software for school use (Penuel, 2006). An extensive amount of research have reported on teachers' use of one-to-one computing in practice (Bergland Holen, Hung, \& Gourneau, 2017; Dunleavy, Dextert, \& Heinecket, 2007; Håkansson Lindqvist, 2015; Lei \& Zhao, 2008; Pegrum, Oakley, \& Faulkner, 2013; Tay, 2016), while only a limited amount of studies have considered teachers' practices in depth. Barr \& Tagg (1995) identified teachers' practice as either teacher-centred or student-centered. In two narrow studies from compulsory school, Bergström et al (2017) and Bergström \& Mårell-Olsson (2018) used the combination of power and control to analyse the continum from teacher-centred practice to student-centred practice. Briefly, the concept of power highlights, for example, to which extent teachers allow students to be part in the design process of a lesson (Klein \& Kleinman, 2002), whereas the concept of control concern teachers' decisions about content, squence, pace, assessment and speech space in a lesson. The rich combinations of power and control relations that can appear in a lesson makes teachers' practice to an intricate process, especially in the one-to-one computing classroom since new resources possibly affect the practice in different directions. This addresses a gap in the litterature, since few studies have considered the power and control relations in upper secondary 
schools with one-to-one computing. The aim is to explore and explain what kind of power and control relations two teachers' practice in upper secondary school constructs. The following research questions were asked:

- What kind of power and control relations can be found in the teachers' practice?

- How are teacher-centered teaching and student-centered teaching constrained or encouraged in the teachers' practice?

\section{TEACHERS' PRACTICE AND CONTROL}

Teaching in one-to-one computing classrooms have been reported to increase the complexity of teachers' work, a matter traced to issues of power and control (Laurillard and Derntl, 2014, Bergström et al, 2017; Bergström \& Mårell-Olsson, 2018). In a study of 64 one-to-one computing classrooms, Jahnke et al (2017) identified both teacher-centered practices and student-centered practices. The characteristic of the teacher-centered practices were described as surface learning and memorizing, while the student-centered practices supported deep and meaningful learning. In the literature, control is described as an aspect of students influence over educational organization regarding decisions about for example methods and content (Player-Koro and Tallvid, 2015). Studies (Fleischer, 2012; Hatakka et al, 2013; Floridi, 2014) have shown that one-to-one computing affect teachers' control with regard to who selects the content. The question of who select content got attention based on the increased choice due to the large amount of content available on the internet. Research shows that one-to-one computing can change the teacher-role and student-role when teachers' practice shifts from teacher-centered practice to student-centered practice (Bergland-Holen, 2017). The shift towards student-centered practices point on increased student influence in what sequence something should be learned as well as how fast they shall acquire content, and that teacher-student interaction differs significantly, for example by adjusting the instruction in response to the students' learning (Rosen and Beck-Hill, 2012). In a longitudinal study, Tay (2016) found that during the third year of study, students started to talk more while teachers talked less. Thus, when considering teachers' practice in the one-to-one computing classroom through the lens of control about content, sequence, pace, evaluation and speech-space one-to-one computing can be considered as a small-step school development project over time (Weston \& Bain, 2010; Bebell \& Kay, 2010; Håkansson Lindqvist, 2015). Further, social media are reported to provide both possibilities and challenges in teachers' practice in the one-to-one computing classroom (Andersson et al., 2014; Blikstad-Balas, 2012). For example, Hatakka et al (2014) found that $73 \%$ of the teachers in their study reported a negative influence on teaching and learning caused by students' use of social media. Such use can be explained as gaps between the multimodality (Kress \& Selander, 2012) of the one-to-one computing classroom in contrast to teachers' practice based on a dominant textbook discourse (Blikstad-Balas, 2012).

\section{RESEARCH METHOD, MATERIAL AND THEORY}

The present study took place at an upper secondary school in the northern part of Sweden in a municipality with an established one-to-one computing initiative. From day one at the school, each student was equipped with a laptop computer. Based on a personal ownership model, the students were responsible for the laptop but were also allowed to take it home after school and during the holidays. Additionally, the classrooms were equipped with digital projectors, an interactive board (Smartboard), and a whiteboard. The whole school had wireless internet access, and access to a learning management system (LMS). The teachers used the LMS for sharing files, links, and syllabuses. At the front of the classroom, the interactive board was most often placed at the center and the whiteboard beside it. The classroom layout had desks in rows, with the teachers' desk at the front. 
Table 1. Profile of the Social Study Classes

\begin{tabular}{|c|c|c|c|}
\hline & Class A & Class B & Class C \\
\hline Total number of students & 20 & 25 & 27 \\
\hline Program & Technology & Construction & Social studies \\
\hline Grade & Third year & Second year & First year \\
\hline Level & Social Studies C & Social Studies B & Social Studies A \\
\hline Topic & Mass Media & $\begin{array}{l}\text { Swedish } \\
\text { constitution and the } \\
\text { European Union }\end{array}$ & $\begin{array}{l}\text { Socio-economics } \\
\text { and personal } \\
\text { finance }\end{array}$ \\
\hline Assessment & $\begin{array}{l}\text { Final exam or extensive } \\
\text { group work assignment with } \\
\text { oral presentation }\end{array}$ & Final exam & $\begin{array}{l}\text { Oral presentation } \\
\text { and final exam }\end{array}$ \\
\hline
\end{tabular}

As shown in Table 1, the two teachers in this study taught three classes in different programs, both academic and vocational. At the time for the study, the Technology Program and the Social Studies Program were academic while the Construction Program was vocational. Social Studies is divided into three levels A, B and C. One teacher taught third year technology program students in Social Studies C. The other teacher taught second year construction program students in Social Studies B, and first year social science students in Social Studies A.

In total, 16 classroom observations were conducted during three weeks of study. The observer documented classroom activities, and noted time indications when things happened. The observations were combined with informal conversations with the teachers. The field notes were developed, as closely as possible to the observation, into "thick descriptions" (Kullberg, 2004, p. 153). Thick descriptions are characterized as narrative, describing, analyzing, and interpreted. The two teachers became what Miller and Crabtree (1999) call "key informants". As a complement to the observations the teachers were interviewed. The interviews followed a semi-structured interview guide covering two themes that aimed to probe the teachers' decisions and motives when teaching with technology. The second theme focused on the use of one-to-one computing with questions about why the teachers chose to use one-to-one computing. The interviews were recorded and transcribed; each one lasted approximately 30 minutes.

The analysis in this paper draws upon Bernstein's (2000) theory concerning the realization of power and control in teachers' practice. Cause (2010) highlight both critique and possibilities of using Bernstein's theory. The critique has especially pointed on the complexity and for being unreadable. Despite these challenges, Bernstein's theory is widely used especially as a theory for understanding teaching through concepts for power and control that can be applied from micro to macro levels. Key concepts for power and control are: classification and framing. The concept power is operationalized in the concept of classification that addresses the relationships between categories e.g. teacher-student. According to Bernstein (2000), categories hold relative power positions, either strong or weak, and any attempt to change the degree of separation in the relationship will reveal the power relationship on which the classification is established. Framing indicates the locus of control in practice, that is, who controls what in pedagogical communication and interaction. Like classification, framing is a relative concept, either strong or weak. A more detailed account of the concept of framing is provided in the following section.

\subsection{Analysis}

Both classification and framing are relative concepts, either strong or weak. These can generate rich variations of power and control in and between teachers' practice. A theory-driven coding scheme (Stebbins, 2001) was developed based on Bernstein's (2000) concept of framing. Framing was used and applied to analyze what Bernstein describes as control through six framing categories: selection, sequence, pace, evaluation, and regarding speech space categories of the teacher-student and the student-student relationships. Bernstein's theory was developed in a time without one-to-one computing. When processing the data, the use of technology played a role in teachers' practice. Therefore, another two categories were developed in the coding scheme: teachers' use of ICT, and students' use of ICT. The extract shows in Table 2 regarding the category selection to describe the teaching approach to content. 
Table 2. Example of Extract

\begin{tabular}{|c|c|c|c|c|c|}
\hline Category & Indicator & $\mathrm{F}++$ & $\mathrm{F}+$ & F- & F-- \\
\hline Selection & $\begin{array}{l}\text { Teacher-student } \\
\text { communication } \\
\text { in practice }\end{array}$ & $\begin{array}{l}\text { The teacher } \\
\text { provides a } \\
\text { teaching } \\
\text { approach } \\
\text { regarding the } \\
\text { content to acquire }\end{array}$ & $\begin{array}{l}\text { The teacher } \\
\text { provides a } \\
\text { teaching } \\
\text { approach } \\
\text { regarding the } \\
\text { content for the } \\
\text { students, } \\
\text { accepting } \\
\text { students' } \\
\text { suggestions }\end{array}$ & $\begin{array}{l}\text { The teacher } \\
\text { provides } \\
\text { different } \\
\text { teaching and } \\
\text { learning } \\
\text { activities to } \\
\text { choose from } \\
\text { without } \\
\text { referring to } \\
\text { priorities and } \\
\text { asks students to } \\
\text { make a selection }\end{array}$ & $\begin{array}{l}\text { The teacher asks } \\
\text { students to } \\
\text { suggest teaching } \\
\text { approaches for } \\
\text { the } \\
\text { course/lesson/cont } \\
\text { ent }\end{array}$ \\
\hline
\end{tabular}

Example of transcripts

$\mathrm{F}++$ "I hear and see that the teacher starts to talk in detail about what they have worked on, and she emphasizes that the students need to take notes since there is a lot of information to acquire (Maria, Observation 3)

F+ "Towards the end of the teacher's introduction, the teacher decides that in forthcoming lessons, the students will have the possibility to select either a teacher-centred assignment or a student-centred inquiry-based assignment." (Christine, Observation 2)

F- "The teacher tells me she used to have a final exam, but it might not be the best approach since the students just had a final exam. The teacher asks the students to choose. Some of the students suggest receiving assignments, others protest. The teacher suggests the possibility of conducting a not-too-comprehensive group project where they [the students] conduct interviews." (Christine, Observation 2)

F-- "The teacher then walks to Johnny and June's group. The teacher stands next to Johnny and asks what the group have in mind. The group have decided to study Twitter and the Arab Spring. The teacher gives feedback on the topic and comments on the students' choice. The teacher says, 'Shouldn't you study what's going on in Syria instead? It is more current.' The students' body language conveys that they are quite uninterested in the teacher's idea." (Christine, observation 14)

Table 2 shows the principle of how the teachers' communication in practice was coded on a relative scale. The coding scheme affords theoretical discrimination of who controls what. Furthermore, the extract includes transcripts documented in the classroom observations illustrating framing that span from very strong to very weak. The material was coded using the software NVIVO based on the eight framing categories above. In addition, the material from the interviews illuminated the teachers' understanding of decisions of designing the observed lessons, in a way their teaching beliefs regarding control, as well as motives to use one-to-one computing.

\section{FINDINGS}

This section presents the results of the study. The two teachers' names have been replaced with pseudonyms: Christine and Maria. Christine taught the technology class (academic) and Maria taught the construction (vocational) and the Social Studies (academic) classes. This section starts with a presentation of how the teachers compared Social Studies with and without one-to-one computing. Fundamentally, Social Studies is a subject based on a context of weak classifications, or blurred boarders between categories (Bernstein, 2000). Such symbolic borders were highlighted in two contextual categories. First, the subject of Social Studies has a strong relationship to one-to-one computing; as Christine said, "Social Studies and the internet go hand in hand." Secondly, and because of the first, neither of the teachers used a textbook in any of the observed lessons. In the interviews, the teachers argued that one-to-one computing has changed the practice of Social Studies. They compared the nature of Social Studies with and without one-to-one computing, highlighting that one-to-one computing simplifies the process of designing inquiry-based teaching and learning compared to methods that involve leaving the classroom. For example, in Sweden, several agencies, like the Swedish Social Insurance Agency, have become e-agencies. Even though study visits and interviews are still used, one-to-one computing reduces the need for such methods in favor of inquiry-based teaching and learning with students' laptops. However, the empirical material indicates two distinct teaching practices based on how the control either was kept by the teacher or dislocated to the students. Not all of the eight categories were found in the 16 observations. 


\subsection{Christine's Teaching Practice}

The below findings are based on 6 classroom observations in the technology program.

\subsubsection{The Teacher-Student Relationship}

In 5 of 6 Social Study lessons in the technology program, Christine's teacher-student communication demonstrates a speech-space based on weak framing, which indicates distribution of control from the teacher to the students. Christine's pedagogical communication was framed by three key features: problematization of content, students' critical capacity, and students' acquisition of certain perspectives. However, when considering control through the category selection of content, Christine's classes indicates an array of both teachers' and students' control when content was selected. An example of distribution of control was when Christine invited the students into the process of decision-making when planning for the semester; in the interview, she said, "They [the students] were given suggestions, like a smorgasbord, which they could choose between at the start of the semester. We then visualized what we needed to do; some reserve topics were also provided."

In Christine's practice, the selection of content is strongly influenced by what happens in the world around, such as the Palestine-Israel conflict, indicating a distribution of teachers' control. However, the control in which sequence content should be acquired demonstrates strong teacher regulation. It was Christine who directed the students' process so they would acquire content in a certain order. The qualitative nature of the material indicates that Christine's design influenced the students because it involved them personally, as students in their final year at upper secondary school. The observations serve to distinguish this nature in relation to the characteristics of one-to-one computing in Social Studies. For example, in one observed lesson, the students were to explore what they could earn in future employment and then study the relationship between taxes and salary. The students were first instructed to search for information and organize it using three different kinds of websites: 1) a freely chosen union site, 2) a tax check site, and 3) a municipality's website containing maintenance support information. Secondly, in the category selection of content, the teacher guided students in a direction based on the assignment structure, indicating strong power and teacher control. The selection of content also involved the students when they could individually choose their dream job and check salaries and how much they would pay in tax, indicating weak framing and student control. The sequence was strongly monitored by the teacher since students needed to do the operation in the suggested order. Christine argued that she wanted the students to problematize the content by asking questions: "What is the money used for? Don't you think it is strange that so much money is allocated for schools? People used to say that the social services receive most of the money. What are your impressions?" (Field note, T1).

Furthermore, in the teacher-student relationship, the problematizing nature of Christine's teaching privileges teacher-student interaction when she asks for students' impressions and challenges them, indicating weak framing and students' control. Christine's questions engaged the students to take a stance and to become critical of what they find in relation to what taxes are allocated for. The above task and field note demonstrate how the teacher strongly guided the students' use of ICT, indicating teachers' control. The students' use of laptops was well integrated, and students were active and conducted the work they were asked to do. In the category students' use of ICT also indicate that social media applications (e.g. Facebook, YouTube) were only minor distractions

\subsubsection{The Student-Student Relationship}

The student-student relationship was observed in all Social Study lessons in the technology program. The empirical material indicates that the student-student relationship has a preponderance towards groups with an open dialogue among the group members, indicating weak classification and framing between students. When organizing such a teaching practice Christine talked explicitly about being critical: "Christine starts to read the schedule in relation to her planning for the next lessons. She says that they [the students] should do things together to become critical and get a variety of perspectives. There will also be a possibility to choose between project work and a final exam." (Field note, T10)

The above field note highlights the students' possibility to select, which indicates distribution of symbolic power from the teacher to the students. Then, in the next lessons, students could choose to study in groups or individually. Regarding the group work, students selected a topic according to criteria specified by the 
teacher. In contrast, for students who selected individual studies, the teacher monitored their work to ensure they acquired the specific predetermined content, which indicates teachers' strong power and control. In the group work, the students selected, for example the Arab Spring. Students were required to choose different tweets on Twitter and other information on social media. They needed to support each other in the group in deciding what would and would not be a useful learning resource, which indicates weak framing and students' control.

\subsection{Marias' Teaching Practice}

Maria taught the social science program students in 3 Social Study lessons, and the construction programme students in 7 Social Study lessons.

\subsubsection{The Teacher-Student Relationship}

In general, for both the construction program and the Social Studies program, Maria's teaching practice indicates strong framing, making the teacher in control of speech-space and content decisions. Independent of program, in almost all observations the modality in the teacher-student relationship demonstrated strong or very strong framing, indicating strong teacher control. In a majority $(\mathrm{N}=6)$ of the observed classes, such designs were based on lectures, for example "the teacher starts to talk in detail what she has presented and sends a hint to the students that in today's lesson they will also [compared to yesterday's lesson] take notes because it is a great amount of content to go through" (Field note C5). Thus, it was Maria who held the control over the speech-space, and it was Maria who decided on the selection of content, the order (sequence) of students' acquisition of content, and what students were expected to acquire in relation to time and preconditions. Such a speech-space is based on communication that mostly goes from teacher to student with limited discussion and explanation. Even though variation exists in the teacher-student communication, the students asked detailed questions with a lack of possibilities for dialogue, for example when students in Social Studies were working in groups of four: "After a couple of minutes, when the teacher stops at one group, Aron asks a question about the number of votes and parliament members, and asks for some advice about expressions. Maria gives the group some advice about expressions and says that they should include the picture Michael found because it is simple and easy to understand." (Field note, SS12)

The above field note indicates strong teacher control based on explicit guidance what content to select and what content to exclude, for example when pointing to Michael's picture. Considering the above field note from another perspective, it illustrates characteristics of the teacher-student communication. Such a speech-space indicates less discussion and more emphasis on strong control towards clarifying what the students should write or say. Even if some variation exists, or evaluation categories were not found, the nature of the communication indicates features of an approach that emphasis looking for the right answer.

Independent of program, the strong control in Maria's classes was also based on her use of one-to-one computing for teaching. She prioritized the use of one-to-one computing that centralizes teaching to the teacher, for example, by using presentations on the Smartboard or showing films. As consequence, the students' use of one-to-one computing becomes regulated towards note-taking activities. In contrast, the oneto-one computing classroom involves a choice for students to use technology either by following the teachers' intention or as a means of distraction (e.g. social media). In the students' use of ICT, independent of program, indicated weak framing and that students excluded themselves from Maria's teaching. Maria sometimes used strong regulation when asking students to pay attention and she instructed students to close their laptop screens, sometimes even physically closing the screens herself. Students responded by picking up and using their smartphones to do other things, indicating symbolic actions of excluding themselves from the teaching.

\subsubsection{The Student-Student Relationship}

Student-student interaction was found in 4 of 10 observations, with a majority $(\mathrm{N}=3)$ in the construction program. The observed group-work activities followed a similar pattern where the activity started in one lesson and stopped in the next lesson. In the interview, Maria reflected on her design when student-student interaction takes place: "Social Studies $A$ is a content-rich module and sometimes rather difficult for the students. I have noticed that, for example, in the construction program from short group-work activities lasting 40-50 minutes they can possibly perform a 2-minute record." Such designs echoed strong framing in 
the categories selection of content, sequence, and pacing for example when Maria for the construction students posed questions like "What kinds of decisions are conducted at the institution?" (Field note C16) Maria asked the students to present their answers to questions that had been assigned to the whole class. Maria reflected on the lesson and expressed disappointment at the students' performance. She had not expected the groups of students to read the answers one by one, which gave the impression that they were not very engaged. When the observer accompanied her on the way back to the staff room, Maria considered the students' performance in relation to the nature of her expectations: "Before I planned this topic, I wondered if they should really do a different assignment, but I thought what the heck, we'll carry on. I can always lecture, but that becomes boring. However, the students' performance was not good, so I need to repeat it [the lesson] again. Hmmm, they learn best from lectures when I talk slowly and they take notes. But we can't do that every lesson." (Field note, $\mathrm{C} 16$ )

The above field note confirms what Maria said in the interview, "I think they [the students] learn best through lectures." Thus, the solution is to strengthen framing in the teacher-student relationship. Maria also wished to provide some variety to her lessons. The design of the observed lessons required students to do what they were asked to do: deliver answers to the teacher's question. However, Maria expected something else, which was not apparent in her design and guidance.

\section{DISCUSSION}

This study has revealed how two distinct teaching practices in Social Studies in upper secondary school were constructed based on how control either was kept by the teacher or distributed to the students. Previous studies have indicated that the concepts of power and control are important for understanding students' possibilities to exert influence in teachers' practice (Laurillard and Derntl, 2014, Player-Koro and Tallvid, 2015; Bergström et al, 2017; Bergström \& Mårell-Olsson, 2018). When considering the first research question regarding power and control relations in the teachers practice, the results provide theoretical discrimination and variation within each teacher's practice, as well as, between the two teachers' practices. That leads us to the second research questions how teacher-centered teaching and student-centered teaching are constrained or encouraged in the teachers' practice. Bergland Holen et al (2017) found a shift from teacher-centered teaching to student-centered teaching in the one-to-one computing classroom. When comparing the two teachers' practice and how they keep or distribute power and control, similar results was found in this study. Christine who taught the older students in an academic program and Maria who taught the younger students in both academic and vocational programs, Christine's practices distributed more power and control to the students. In contrast, Maria's practice demonstrated strong teacher control in both the speech space and in the decisions. Especially, Christine's practice reflects characteristic to Social Studies as blurred boarders between categories, for example, in situations where students use content that is not predetermined such as tweets on Twitter. The distribution of power and control enabled the student-centered practice in Christine's classes, while Maria who kept power and control is understood as a teacher-centered practice.

Further, when comparing the both teachers' use of ICT, Maria frequently used ICT for teacher-centered teaching but also that the students used their laptops or other devices to take control when they virtually left the lesson and the teachers' teaching. Whether it is academic or vocational program, students do not seem concerned. That can be understood as a sign of strong student power, since they break the rule of listening to the teachers' lecture. Blikstad-Balas (2012) found similar results which was explained as two different discourses competing. A previous textbook dominated discourse, in contrast to a new discourse of internet-based content. Floridi (2014) pointed on the fact that the great impact of the internet means that information is not something on behalf of the teachers. Thus, the learning resources constrain the shift from teacher-centered teaching to student-centered teaching especially in Maria's practice. One-to-one computing possibilities has been identified as giving students a growing number of choices, due to the increase in resources (Fleischer, 2012; Hatakka et al., 2012).

Even though Christine does not distribute all control to the students in the eight framing categories (selection, sequences, pacing, evaluation, teacher-student relationship, student-student relationship, teachers' use of ICT, and students' use of ICT) and that they are in the final year in an academic program, the control she does distribute to the students seems to be a meaningful learning experience (Jahnke, et al, 2017) about 
issues that affect students in their life and beyond. Therefore, introducing one-to-one computing into daily teaching and learning is an intricate process for teachers as well as for the school organization (Weston \& Bain, 2010). When reflecting upon the two distinct practices, especially from the teacher Maria's perspective, the results highlight the intricate process, and challenge, of how to design teaching and learning with one-to-one computing that support students' meaningful learning. One approach could be to use real world problems (Jahnke et al, 2017) that possibly affect students in their life and near future.

\subsection{Limitations}

This study contains some methodological limitations. One limitation concerns the unequal amount of observations between the two teachers and between the programs. This was unavoidable due to overlaps in the schedules and consequently, we may have also lost important information about teachers' teaching. A second limitation concerns how the data were collected during the classroom observations. With field notes, the observer selects the situations to document; video or audio recordings provided other opportunities to select and assess critical situations afterwards. In order to strengthen the classroom observations, teacher interviews complemented and confirmed some of the observed episodes. Nevertheless, the results of the study still contribute to the research field.

\section{CONCLUSION}

This study aimed to explore and explain what kind of power and control relations two teachers' practice in one-to-one computing classroom in upper secondary school constructs. The teachers' practices showed two distinctive patterns here addressed as teacher-centered practices and student-centered practices. The teacher-centered practice was based upon strong power and control relations. Such an approach demonstrated the teacher as a lecturer, short paced actives, increased use of social media for virtually leaving the classroom and thereby challenging the teachers' power. The second pattern of student-centered teaching was based on real world problems that affected the students in their life which can be considered as meaningful tasks. This practice was based on distribution of power and control to the students. Further, Bernstein's concept of power and control both discriminate and problematize the possibilities and challenges in teachers' teaching with one-to-one computing in Social Studies. An implication is that the control concept through the eight categories are general; that they should be applicable in other school subjects. This study confirms what other studies (cf. Weston \& Bain, 2010) have shown: that one-to-one computing is a school development project.

\section{REFERENCES}

Andersson, A., et al. (2014). Reclaiming the students: Coping with social media in 1:1 schools. Learning, Media and Technology, 39(1), 37-52. doi: http://dx.doi.org/10.1080/17439884.2012.756518

Barr, R.B. \& Tagg, J. (1995). From teaching to learning - A New Paradigm for Undergraduate Education. Change, November/December.

Bebell, D., \& Kay, R. (2010). One to one computing: A summary of the quantitative results from Berkshire Wireless Learning Initiatives. The Journal of Technology, Learning and Assessment, 10(2), 1-60.

Bergland Holen, J. et al. (2017). Does one-to-one technology really work: An evaluation through the lens of activity theory. Computers in the schools, 38(3), 329-349. Doi: 10.1080/07380569.2017.1281698

Bergström, P., Mårell-Olsson, E., \& Jahnke, I. (2017). Variations of symbolic power and control in the one-to-one computing classroom: Swedish teachers' enacted didactical design decisions. Scandinavian Journal of Educational Research. doi:10.1080/00313831.2017.1324902

Bergström, P., \& Mårell-Olsson, E. (2018). Power and control in the one-to-one computing classroom: students' perspective on teachers' didactical design. Seminar.net: media, technology and lifelong learning, 14(2), 160-173.

Bernstein, B. (2000). Pedagogy, Symbolic Control and Identity: Theory, Research, Critique (Revised Edition ed.). Lanham: Rowman \& Littlefield Publishers, Inc.

Blikstad-Balas, M. (2012). Digital literacy in upper secondary school: What do students use their laptops for during teacher instruction? Nordic Journal of Digital Literacy, 7(2), 81-96. 
Cause, L. (2010). Bernstein's Code Theory and the Educational Researcher. Asian Social Science, 6(5), 3-9. doi:http://dx.doi.org/10.5539/ass.v6n5p3

Crabtree, B. E., \& Miller, W. L. (1999). A Template Organizing Style of Interpretation. In B. E. Crabtree \& W. L. Miller (Eds.), Doing qualitative research (2 ed.). Thousand Oaks, California: SAGE.

Dunleavy, M., et al. (2007). What added value does a 1:1 student laptop ratio bring to technology-supported teaching and learning? Journal of Computer Assisted Learning, 23, 440-452.

Fleischer, H. (2012). What is our current understanding of one-to-one computer projects: A systematic narrative research review. Educational Research Review, 7, 107-122. doi: http://dx.doi.org/10.1016/j.edurev.2011.11.004

Floridi, L. (2014). The 4th revolution: How the infosphere is reshaping human reality. Oxford: Oxford University Press.

Hatakka, M., Andersson, A., \& Grönlund, Å. (2012). Students' use of one to one laptops: a capability approach analysis. Information Technology \& People, 26(1), 94-112. doi:10.1108/09593841311307169

Håkansson Lindqvist, M.. (2015). Gaining and Sustaining TEL in a 1:1 Laptop Initiative: Possibilities and Challenges for Teachers and Students. Computers in the Schools, 32(1), 35-65. doi:10.1080/07380569.2015.1004274

Jahnke, I., et al. (2017). Digital Didactical Designs as research framework: iPad integration in Nordic schools. Computers \& Education, 113(October), 1-15. doi:10.1016/j.compedu.2017.05.006

Kress, G., \& Selander, S. (2012). Multimodal design, learning and cultures of recognition. Internet and Higher Education, 15, 265-268. doi: http://dx.doi.org/10.1016/j.iheduc.2011.12.003

Kullberg, B. (2004). Ethnography in the classroom [In Swedish: Etnografi i klassrummet] (2nd ed.). Lund: Studentlitteratur.

Lei, J. \& Zhao, Y. (2008). One-to-one computing: What does it bring to schools? Journal of Educational Computing Research, 39(2), 97-122.

Laurillard, D., \& Derntl, M. (2014). Learner Centred Design - Overview. In Y. Mor, H. Mellar, Warburton, Steven, \& N. Winters (Eds.), Practical design patterns for teaching and learning with technology (pp. 13-16). Rotterdam/Boston/Taipei: Sense.

Klein, H.K., \& Kleinman, D.L. (2002). The social construction of technology: Structural considerations. Science, Technology and Human Values. 27 (1), 28-52.

Pegrum, M., et al R. (2013). Schools going mobile: A study of the adoption of mobile handheld technologies in Western Australia independent schools. Australian Journal of Educational Technology, 29(1), 66-81.

Penuel, W. R. (2006). Implementation and effects of one-to-one computing initiatives: A research synthesis. Journal of Research on Technology in Education, 38(3), 329-349.

Player-Koro, C., \& Tallvid, M. (2015). One laptop on each desk: Teaching methods in technology rich classrooms. Seminar.net: media, technology and lifelong learning, 11(3).

Rosen, Y., \& Beck-Hill, D. (2012). Intertwining digital content and a one-to-one laptop environment in teaching and learning: Lessons from the Time To Know Programme. Journal of Research on Technology in Education, 44(3), 225-241.

Stebbins, R. A. (2001). Exploratory research in the social sciences (Vol. 48). London: Sage Publications, Incorporated.

Tay, H. Y. (2016). Longituninal study on impact of iPad use on teaching and learning. Cogent Education, 3((1127308)), 1-22. doi:10.1080/2331186X.2015.1127308

Weston, M.E., \& Bain, A. (2010). The end of techno-critique: The naked truth about 1:1 laptop initiatives and educational change The Journal of Technology, Learning and Assessment, 9(6), 1-25. 